\title{
Miracles in the Neo-charismatic movement: Historical and theological critique
}

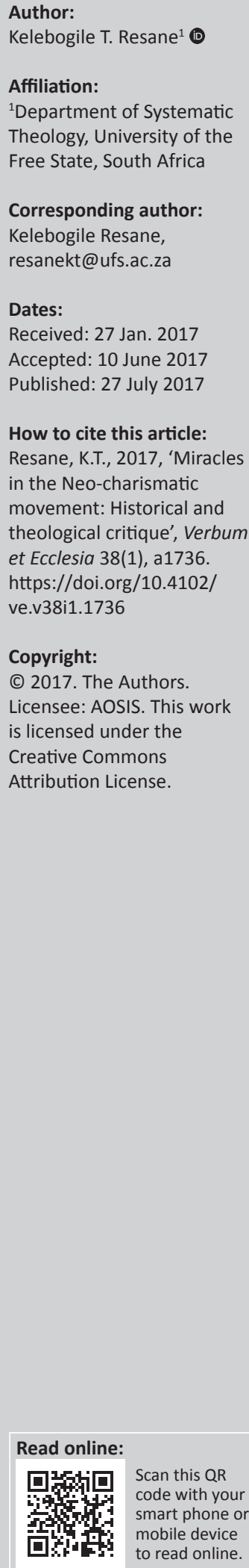

The focus of this article was to explore the historical, theological and biblical miracles in light of the modern-day miracles in the Neo-charismatic churches. It is hereby intended to address and redress these manifestations to evaluate their authenticity and genuineness. The history regarding miracles in this article starts with the Reformers, such as Martin Luther and John Calvin. The historical scholarliness unfolds through the centuries to show how philosophies and theology grappled with this subject. The climax is the theological debate in the 20th century leading to the current miraculous signs in the Neo-charismatic churches in South Africa. The solution is the teaching on proper hermeneutics.

Intradisciplinary and/or interdisciplinary implications: This article focuses on interdisciplinary, that is, church history, systematic theology and ethics in ecclesiastical practices of the Neo-charismatic churches. The article contributes towards the historical knowledge, identifying some constructive theological understanding of authenticity of miracles, as opposed to the modern way of miracles. It opens opportunity for a systematic theological discussion on miracles in Neo-charismatic churches.

\section{Introduction}

South Africa is currently caught in amazement of some activities in the Neo-charismatic churches. The devotees are made to eat grass, drink petrol, eat flowers, et cetera. For instance, it was reported in Times Live on 11 July 2015:

Members of Prophet Penuel's End Times Disciples Ministries in Soshanguve, Pretoria ate parts of a snake, believing it would become chocolate. Images posted onto the church's social media sites show Penuel dangling a live snake and dropping it into the mouths of his congregants. (n.p.)

The puzzlement goes beyond the borders. One reads and hears of some 'miracles' happening in Nigeria, where recently the country was plunged into mourning because of loss of lives. People went there because they seeked miracles. The public television stations of paid DSTV channels have a number of telecasts of tele-preachers claiming to perform miracles. Christians from mainline Christianity abandon their catechesis and paradosis to pursue these manifestations. Many questions regarding the authenticity of these miracles and of course, the ethical integrity of those performing them, are inevitable. This will never be considered without questioning the theological credentials of these performers. Also at question is if these manifestations are the divine hilaritas (cheerful intervention) or counterfeit of God's reality and workings within humankind.

In order to address and redress the phenomenon, one needs to look into miracles from the theological perspectives, including the church history's unfolding thoughts.

\section{Theological understanding of miracles}

The Old Testament with its historicity is the book of miracles (Merrill 1994:33). From the creation story to the post-exilic resettlement, miracles happened. The people of the Old Testament perceived miracles as God's great providential act on their behalf, and as the very foundation of their existence as a community. Warrington (2008:268) referring to healings as part of miracles reinforces that 'The OT presents God as the healer of people and this helps define him as God'. God was voluntarily suspending the regular operation of natural processes for self-revelation to humanity; and these miracles were seen as events of prophetic interpretations of history in terms of what the prophets believed God did (Merrill 1994:33). The people's faith in God was confirmed because their experiences of God's presence in their midst revealed divine grace and judgement in some extraordinary manifestations. Miracles were seen as the incarnation of God among his people. The people were never used 
to these manifestations, because they were not just sporadic, but were a continuum of experience in their lives. Generally, 'as with OT prophets and Charismatic leaders - an indication of the power of God at work' (Kärkkäinen 2013:65).

On the other hand, the New Testament is also full of miracles. From Jesus to the apostles, miracles were their daily experience. However, it is noteworthy to understand that, especially with Jesus, miracles and kerygma worked symbiotically. The preaching of the gospel and miracles were always moving in collaboration. Jesus used miracles and signs to reveal self-identity, making the mysterion a reality to be reckoned with (Jn 10:38). His identity is that of deity - God in essence and truth tabernacling among his people. His deity and power are inseparable. His identity and incarnation coexist and are demonstrated by miracles. They were God's approval of the ministry of Jesus:

Rather than done by Beelzebub, the mighty deeds are the function of the Spirit of God (Mark 3:20-30) - they are God's business. The favorite terms terata and séméia should be taken in their basic meaning, namely, as 'signs'. They point to God's power at work for salvation and deliverance vis-à-vis contestation to the contrary, in arguments that the miracles had their origin in the opposing evil forces. (Kärkkäinen 2013:65)

The apostolic mandate was given with the assurance of the accompanying miracles (Mk 16:17-18). The confirmation of the authenticity of their kyrugma was the accompanying miracles. Preaching Christ and miraculous signs brought awe to their audiences. This calls for the reflective evaluation of the current ministry models promoting miracles. Central to these modern-day miraculous models is health and wealth. These two concepts encapsulate issues such as deliverance from all sorts of curses, regaining the lost treasure, freedom from demonic oppression, et cetera. These models demand ecclesiological scrutiny because:

Theological models need to bring together disciplined analysis of the context, faithfulness to the Christian tradition, and innovation in developing contextual theological categories to inform ministry. The healing ministry is an important area for such construction. (Bate 1999:179-180)

\section{Miracles from Reformation to the present}

The founder of the Reformation in Germany, Martin Luther (1483-1546), understood the miracles of Jesus as the divine works, wrought by the power of God himself. He asserted, but also downplayed the significance of the miracles of Jesus. This is attested by one of Luther's leading Christologists, Dr Ian D Kingston Siggins (1970):

They were great miracles and startling deeds, unparalleled, unprecedented. Yet in Luther's thinking they play an incidental role: miracles themselves are the least significant of Christian works, for the devil was defeated by weakness, not magnificent miracles; the earthly effect of Christ's miracles cannot compare with the heavenly effect of faith in Him; and it is one of St. John's superiorities over the Synoptics that he stresses faith where they stress miracles. (p. 41)

Luther was of the opinion that the miracles of Jesus were not purely manifestations of Jesus' divinity, but the works of the Word of the Father that became incarnate in Jesus (Brown 1984:13). He saw miracles having their place alongside the other soteriological works of Christ. Miracles, according to Luther, are not the direct expressions of deity through which God incarnate can be beheld. Like other soteriological acts of God, miracles can be described as God's masks or garments. This does not mean that Luther thought of miracles as having no evidential value or that they are devoid of spiritual significance. His argument is that miraculous evidence alone is not enough; there must be also a heart transformation. Miracles, therefore, are like visible, tangible expressions of Christ's teaching (Brown 1984:14).

As for John Calvin (1509-1564), his miracles' perspective was forthrightly polemical. As early as 1536, in the preface of his famous Institutes of the Christian Religion, he 'plunged into a discussion of the value and corroborative function of miracles' (Brown 1984:15). In fact, Calvin's theology of miracles is very relevant to the current situation this article is concerned about: where people are made to eat grass or drink petrol. There is an intrinsic connection between miracles and truth. Calvin:

insisted that where a miracle is associated with false teaching, it should be dismissed as Satanic deceit. Hence, 'those miracles' which our adversaries point to in their own support are sheer delusions of Satan, for they draw people away from the true worship of their God to vanity. (cf. Dt 13:2ff.; Brown 1984:15)

Calvin's theology of miracles appeals to both the Old and the New Testament, whereby miracles are to confirm, attest or seal the truth that God is among his people. For Calvin, the glorification of anything other than God is a mark of untruth. Truth in religion is the desire to seek the glory of God. In depth and insight into miracles, Calvin pointed out that miracles are not human-focused but God-focused. He continued to spell it out that he:

did not dispute the capacity of many to work wonders. The decisive factor was the claims made by those who performed them. If those claims led away from the gospel, the wonder was to be rejected. (Brown 1984:16)

The two Reformers differ in their theological perspectives of miracles. Although Luther's approach to miracles as the works of the Word of the Father that was incarnate in Jesus, Calvin attributes miracles to the second person of the Trinity. The two Reformers are in agreement, however, that miracles are sacramental signs embodying and exemplifying God's gracious promises. Miracles are the confirmation of the promises of God in his Word. Indeed the Reformers' conviction was that:

miraculous healings were signs of a transcendent deity, but they were immanent signs also, indications that God of the heavens was also present on earth and involved in the lives of people. (Yong \& Anderson 2014:199) 
Generally, the Reformers' view is that miracles were not sought as a basic ground for belief in God. Miracles are signs that identify the performer as an agent of God. They were viewed as gospel demonstration expressing God's loving care, righteousness, creative power and glory. This fact is highlighted by Yong and Anderson (2014) that:

The Renaissance and Reformation not only produced more critical postures and analytical approaches to miracle accounts but also brought about a more christological focus among Protestants. (p. 199)

The 17th century saw the rising of the modern science with Isaac Newton's physics as the primer for creation of selfsufficient mechanistic universe. The era of this century and its successive 18th century were clouded with the emergence of philosophies such as rationalism and empiricism. These philosophies questioned the validity of religion, especially truth in its essence. The universe was deemed as an autonomous closed system, God's good creation, where he has freedom of movement. Religion, science and philosophy interacted to give meaning to life.

Miracles were attacked and denied. Benedict Spinoza (16321677) was the champion of this denial. His Jewish-Portuguese parentage could not support him as a new settler in Holland where he started to express his views. His critique of miracles is contained in his Tractatus Theologico-Politicus (Elwes 1955:81) published in 1670. He identified God with nature - deus sive natura, by which he believed that there was a supreme, single ultimate reality that could be called God or nature. This made him a pantheist - belief in single supreme reality with many different facets. Spinoza concluded that:

we cannot gain knowledge of the existence and providence of God by means of miracles, but... we can far better infer them from the fixed and immutable order of nature. (Elwes 1955:86)

Thomas Hobbes (1588-1679) is known as a pioneer of empiricism. His opinions are captured in his masterpiece: Leviathan, or the Matter, Form and Power of a Commonwealth, Ecclesiastical and Civil (1651). In this he argued for the absolute sovereignty of the state and the need for conformity in religion (Brown 1984). His discussion of miracles is in Chapter 37 of this writing. He claims:

A miracle is a work of God (besides His operation by the way of nature, ordained in the Creation) done for the making manifest to His elect the mission of an extraordinary minister for their salvation. (p. 34) ${ }^{1}$

This quotation leads to two conclusive remarks that can capture Hobbes' view on miracles. Firstly, that in all miracles the work done is not the effect of any virtue of the prophet because it is the effect of the immediate hand of God; that is to say, God hath done it, without using the prophet therein as a subordinate cause.

Secondly, no devil, angel or created spirit can do a miracle. For it must either be by virtue of some natural science or by

1.There is a subsequent discussion following this quotation from C. Brown to express Hobbes' interpretation of miracles. The discussion is summarised here. incantation, that is, virtue of words. Hobbes concludes that the purpose of miracles is to provide divine attestation. This was a generally accepted view of empiricist thinkers of the 17th century especially the likes of John Locke (1632-1704).

The 18th century scholars went further by enhancing the empirical views by denying the authenticity of the miraculous. The champion of this approach was David Hume (1711-1776). His famous essay; 'Of Miracles' concludes that a miracle is a scientific impossibility; and can never provide a satisfactory basis for religious belief (Brown 1984:80).

The 19th century is known as the golden age of the climax of theological liberalism. In history epochs, it is referred to as the Age of Enlightenment. Foundationally, one recalls the prevailing humanistic philosophy championed by the German philosopher called Immanuel Kant (1724-1804). This humanism was where humans were to express their being by the motto: Sapere aude - 'Dare to be wise'. The supernatural explanations were replaced by the natural ones. Reason, not faith, was an appealing instrument in answering life questions. Kant's beliefs in miracles are expounded in his writing masterpiece: Religion within the Limits of Reason Alone (1793). Conceptually, Kant dismissed miracles as irrelevant to natural religion. He felt no need to disprove them. He was of the opinion that miracles do not warrant the affairs of life because they are of the unknown cause. He warned against any appeal to the miraculous in everyday life. There are other authors of the era who also wrote in line with Kant, notably Hermann Samuel Reimarus (1694-1768) and Gotthold Ephraim Lessing (1729-1781). While Reimarus dislodged miracles as the article of faith, Lessing regarded miracles as history that is incapable of demonstrative proof (Chadwick 1956). ${ }^{2}$ The subject of miracles during the Enlightenment is widely written and read with many other sceptics of the day. Exploration in each of them calls for extra paper on the matter. ${ }^{3}$ However, the bottom line is captured succinctly by Kärkkäinen (2016):

Whereas pre-Enlightenment theology took miraculous acts as proof of the divinity of Jesus of Nazareth, the Enlightenment epistemology rejected their factual and historical nature. (p. 371)

While the debates regarding miracles by the deists and the sceptics were rife in the 18th and the 19th centuries, the Church responded apologetically to defend the theological and canonical didache about miracles. For instance, John Henry Newman, in his Two Essays on Biblical and Ecclesiastical Miracles defined miracles in terms of events that were inconsistent with the laws of nature. He supported Luther and Calvin, and of course, had to deal with the cessationists,

2.Although this historical fact is from Chadwick, perhaps the best account of Lessing's theology is G Pons German publication of 1964.

3.Notable scholars of this era include the likes of Moses Mendelssohn (1729-1786) who was of the opinion that miracles were not necessary to convey God's eterna truths to humanity, but are just the instruments to teach the truth. Friederich Schleirmacher (1768-1834) reluctantly acknowledged the historicity of miracles Schleirmacher (1768-1834) reluctantly acknowledged the historicity of miracles and downplayed their significance. David Friedrich Strauss (1841-1860) held a narrow view of miracles and embraced modern philosophy of science that denied the divinity of Christ. Ludwig Andreas Feuerbach (1804-1872) held that a miracle is a supranaturalistic wish realised - an essential object of Christianity, i.e. an article of faith. Ernst Troeltsch (1865-1923) who ruled out belief in miracle stories of the past because they bear no analogy to present experience; and Soren Kierkegaard (18131855 ) the existentialist who championed the doctrine of the leap of faith. 
that is, those who believed that miracles ceased with the apostolic age. Newman the Protestant (Anglican) later became a Catholic and continued to defend miracles postapostolic and church fathers' age. The Catholic Church officially reaffirmed its position on the credibility and evidential character of miracles.

The First Vatican Council (1869-1870) pronounced that because miracles and prophecies so excellently display God's omnipotence and limitless knowledge, they constitute the surest signs of divine revelation, signs that are suitable to everyone's understanding. ${ }^{4}$

The Protestant orthodoxy was flooded with scholars who wrote and argued extensively about justification and the authenticity of miracles. This was championed by William Paley (1743-1805) who believed in God the Creator of the universe, with the ability to interrupt the course of nature, and that such interruptions are justified by divine purposes. Miracles attest the divine revelation, and once the revelation is attested, there is no further need of miracles. Some were for, while some were against. The bottom line is that the majority of the Protestants were in agreement with the Reformers concerning the theology of miracles. The fact of the matter is that:

From Paley onward, orthodox theologians on both sides of the Atlantic repeatedly acknowledged the importance of approaching miracles within a framework of belief about God. (Brown 1984:167)

By the dawn of the 20th century, miracles were theologically accepted as the supernatural and divine intervention of God in the humanly impossible circumstances. This century is known for the emergence of the neo-orthodoxy. For the conservative evangelicals, neo-orthodoxy suggests 'compromise and failure to recognise God's truth in the Bible for what it is', while to the radical leftists:

it denotes an anachronistic attempt to revive the orthodoxy of the early church and the Reformers in a way that pays only lip service to the realities of modern thought. (Brown 1984:239)

The well-known scholars of the era are the 'triple B's' known as Emil Brunner (1889-1966), Karl Barth (1886-1968) and Rudolf Bultmann (1884-1976). These three theologians were at loggerheads with each other, with Bultmann being the most radical of the three. Bultmann is well known for his demythologisation of the worldview of the New Testament, and therefore also of the miracles of Jesus, especially in the Gospels of Mark and John.

For Brunner (1934), miracles, though central to the Bible religion, were an embarrassment to modern immanentism. ${ }^{5}$

4.Constitutio Dogmatica de Fide Catholica, ch.3; cf. Canons 3 and 4 (The Church Teaches: Documents of the Church in English Translation [St. Louis: B. Herder Book Co., 1960 ed.], \#64; cf. \#\#71, 72; Latin in Enchiridion Symbolorum definitionum et Declarationum de Rebus Fidei et Morum, ed. H. Denzinger, rev. A Schönmetzer, 32nd ed. [Barcelona, Freiburg, Rome: Herder, 1963], \#\#3009, 3033, 3034).

5.In his massive and influential book The Mediator, published for the first time in 1927 , he relegated the subject of miracles to a footnote and took over to rectify the subject in his second volume of Dogmatics where he briefly defended the propriety of belief in miracles and included an appendix on the question of miracles and demythologising.
They were 'signs' of Christ, and 'as such they should be studied and pondered with as much earnestness as His words' (Brunner 1934:42). As for Barth, he:

saw miracles as revelatory signs, or acts of God illustrating and proclaiming the message as the Word of God... they have a positive function as a demonstration of Christ's person. (Brown $1984: 241)^{6}$

Miracles are hidden from us, though they reveal Christ for us to believe and honour him as Creator and Lord. They are the displays of the divine omnipotence. Bultmann was christological in his theology, aiming to restore the dimension of the transcendence of God to the 20th century Christianity by proclaiming the central significance of the cross and the resurrection of Christ. The Gospels, especially those of Mark and John, were his analytical premise that their stories were created to preserve and to detect the Sitz im Leben - life situation of the early church. For Bultmann, 'a new form implied new content' (De Klerk \& Schnell 1987:165).

\section{In a nutshell, Brunner was:}

apologetic, and centred on the formal question of the feasibility of miracles in the context of God's relations to the natural world... while Barth declared that miracles were mysteries of the sovereign activity of God. (Brown 1984:241)

\section{The Neo-charismatic phenomenon of the 21st century}

Suppositional observation can deduce that the Spirit Movement of the postmodern era is growing exponentially and at an alarming rate. In South Africa, the mainline Christianity suffers a set-back. The exodus from the liturgical Christianity to the new movement is momentous and seems unstoppable. The dawn of democracy opened the doors for the Neo-charismatic churches, especially those from West Africa (especially Nigeria) into the South African Christian terrain. It is not only the mainline denominations suffering this emptiness, but also the classical Pentecostal churches of the 20th century, such as the Apostolic Faith Mission, Assemblies of God, Full Gospel Church of God, et cetera. These churches are constantly experiencing schisms as some of their devotees catch the spirit of the age where gospel power is witnessed in demonstrations such as healing, breakthroughs out of depression, wealth, et cetera. The prominent Nigerian churches attracting many adherents out of these traditions are Christ Embassy of Pastor Chris Oyakhilome; The Redeemed Christian Church of God (RCCG) of Josiah Akindayomi; Winners Chapel, also known as Living Faith Church Worldwide of Bishop David Oyedepo; Synagogue Church of All Nations of Pastor Temitope Bologun (TB) Joshua, et cetera. They make such a great influence where these manifestations are the centre of attraction. However, RCCG is difficult to categorise it strictly to these manifestations, because of its diverse polity and proclivity towards evangelical practices. The South African prominent churches following this trend are the Rivers of Living Waters

6.One has to go through Barth's nine volumes of Church Dogmatics to glean that his reference to Jesus' miracles is passing allusions. 
Ministries (Bishop Zondo); Rabboni Centre Ministries (Pastor Lesego Daniel); Incredible Happenings Ministry (Prophet Paseka Motsoeneng aka Mboro); Tyrannus Apostolic Church (Apostle Simon Mokoena), et cetera.

The South African society went through writhing pains of agony and grief because of the loss of about 80 lives on a pilgrimage to Lagos, Nigeria, in September 2014. The historic tragedy of the collapse of Pastor TB Joshua's church guesthouse on the 12th September leaves theological analysts with the question of people crossing the borders to seek the miraculous experiences at a particular cultic centre. The recent miraculous events that sent the shock waves were those by Pastor Lesego Daniel who made his congregants to eat grass, drink petrol and eat flowers. Watching these incidents on the television and media in general clearly shows the acts of manipulation that cannot be cited as miracles. One Sunday Times Lifestyle Magazine's columnist relays her discussions with her friends about Pastor Lesego Daniel's petrol-drinking congregation:

Some friends suggested that the controversial pastor should be arrested for endangering his parishioners. Still others suggested that the flower-eating, petrol-guzzling 'it tastes just like pineapple juice' members be arrested for mass stupidity. Still others thought the Commission for the Promotion and Protection of the Rights of Cultural, Religious, and Linguistic Communities should have been involved. The last lot never quite highlighted the commission's potential role, since I have never heard that it prosecutes anyone for religious beliefs that are detrimental to citizens' health. (Wanner 2012:n.p.)

The DRUM Magazine (09 October, 2014) journalists (Mokubung, Ngcobo \& Ngwenya, 2014) wrote an article in which the local miracles makers join the debate concerning the collapse of the building in Nigeria, and Prophet TB Joshua in general. Pastor Lesego Daniel apologetically defends Pastor TB Joshua, while Pastor Paseka Mboro Motsoeneng is critical towards the Nigerian prophet. One of the salient features of the Neo-charismatic preachers is the lack of theological essence in their debates. This is because of their low esteem towards theological analysis, insights or debates. This absence or shallowness of theological insight is replaced with unconventional practices tagged miracles. Both their ecclesiology and Christology are always on personal convictions rather than in the hermeneutical principles of the Bible. Hence, their ministries are exceedingly egocentric in structures, methods and objectives. Shenk (2005) argues that missions in the end times:

will take place in a situation of claims and counter-claims. Many pretenders will proclaim themselves to be messiah, but these false messiahs cannot deliver what they promise (Mark 13:6, 21-22). Messianic options can also take the form of ideological and revolutionary movements that claim they will liberate humankind from its present dilemma. (p. 77)

\section{Theological critique of the miracles in the Neo-charismatic movement}

A miracle is when God (not an apostle, prophet, evangelist or pastor) breaks the rules of nature to reveal his power or will in a humanly impossible situation. A miracle cannot be orchestrated or demonstrated. It takes audiences by surprise and leaves them baffled. The thesis is clear that a miracle is an occurrence which is contrary to what is known of nature. The British theologian, Macquarrie (1971), correctly asserts that theologically:

a miracle is understood not just as a happening that excites wonder but as an act of God. Such an act may be a vehicle for revelation or for grace or for judgement or for all of these together. (p. 226)

Kärkkäinen (2016:371-372) goes into details to define the New Testament concept of miracles thaumasia, meaning 'marvels'. What makes a miracle miraculous is not that it is against nature, but that 'it surpasses the faculty of nature and hence is God's work' (Kärkkäinen 2016:372), 'and hence is God's work, hidden to human understanding' (Kärkkäinen 2015:187). A miracle is providentia ordinaria, that is, God is fully involved with it through second causes in accordance with the laws of nature. It is an event that breaks into the order of nature. But a miracle is also providentia extraordinaria, that is, when God works immediately or without the mediation of the second causes in their ordinary operation. A miracle happens when regular procedures of nature are suspended for a cause. One of the 20th-century theologians, Berkhof (1941), cautions us that:

The distinctive thing in the miraculous deed is that it results from the exercise of the supernatural power of God. And this means, of course, that it is not brought about by secondary causes that operate according to the laws of nature. If it were, it would not be supernatural (above nature), that is, it would not be a miracle. (p. 176)

This explanation calls into question the acts of people eating grass and drinking petrol. The leader is totally involved in orchestrating the events by giving commands as to what actions are to be initiated. The agent is in charge and directs the events towards his desired goals. There is no obfuscation to open devotees' eyes and minds to Jesus. It is therefore theologically legitimate to examine these practices in the light of orthodoxy regarding doctrine and discipline in their context. 'An authentic response to a context like this requires a response to the complexus of truths, beliefs and values within the context' (Bate 2012:72).

One quality of a miracle is that it occurs unpretentiously and modestly (Van der Meer 1966:181). This brings a spotlight to the methods applied by the Neo-charismatic leaders mentioned above. Watching the videos of miraculous healings at Synagogue Church of All Nations, whose building collapsed in Nigeria recently, one wonders of the place and the role of modesty and human dignity when people expose their nakedness in front of the audiences to prove their health status or the divine interventions. People vomiting and urinating blood in front of the masses questions the chastity and authenticity of these events. Truthfully:

a miracle done by the God of Christianity will be of a character which is in harmony with the mind and spirit of Christ. This is a moral criterion. (Moule 1966:27) 
Another quality of a miracle is its divine orchestration as opposed to human demonstration. Most, if not all, of these 'miracles', are human initiated. It is the preacher that the devotees look to, not God. The theological validation of miracles is that God is the primun movens - the prime mover. Jesus Christ never received any reward after a miracle. His miracles were divinely orchestrated, hence left people with wonderment. This fact is highlighted by Kasper (1985:92) that miracles as acts of power (dunameis) and signs (séméia) 'are extraordinary, unexpected events which provoke amazement and wonder'. Jesus never called people to come and witness a miracle. His miraculous acts happened unpretentiously and spontaneously without any call towards himself. Hence, people in bewilderment could exclaim: 'What kind of man is this? Even the winds and the waves obey him!' (Mt 8:27):

Miracles are also called 'wonders'. They stunned and amazed those who saw them. When Jesus healed a lame man, the response was: 'This amazed everyone and they praised God saying, 'We have never seen anything like this' (Mark 2:12). By these acts of power and signs and wonders, God was seen to be performing miracles through His Son. (Price \& Price 1995:83)

Miracles are not the mark of spirituality or in consonance with theological correctness. The performance of miracles is not the sign of authentic discipleship. The performers are to be verified as to by which spirit are they doing these things?

Not everyone who says to me, 'Lord, Lord', will enter the kingdom of heaven, but only he who does the will of my Father who is in heaven. Many will say to me on that day, 'Lord, Lord, did we not prophesy in your name, and in your name drive out demons and perform many miracles?' Then I will tell them plainly, 'I never knew you. Away from me, you evildoers! (Mt 7:21-23)

The morality and the character of the performers should be under the scrutiny of the biblical orthodoxy. The performer and the act itself must be synchronically aligned. Church history has proved that the false prophets do not last long. They either align to the orthodox confession of faith, or disappear from the theatrum gloriae Dei - the arena within which the glory of God may be discerned and recognised ${ }^{7}$ :

By their fruit you will recognize them. Do people pick grapes from thornbushes, or figs from thistles? Likewise every good tree bears good fruit, but a bad tree bears bad fruit. (Mt 7:16-17)

This fact is taken further by Bate (2012) that:

A local theology needs to provide a Theological Anthropology which incarnates the theology in the local context and culture, a Biblical Theology which roots the theology in the Scriptures and an Ecclesiology which roots the local theology in the tradition and teaching of the Church. (p. 80)

By nature, the miracles performance is one of the corollary charismata. These charismata do not operate on their own. They are accompanied by other gifts to verify or confirm their authenticity, validity and theological correctness. As a

7.John Macquarrie (1997:3-47) referred to this as the idea of John Calvin, adopted by Karl Barth, referring to History. corollary gift, miracles performance is subject to discernment. Discernment is a process when the community of faith converge to wisely reflect, debate and contemplate on the miraculous phenomenon, to see how valid or authentic is the phenomenon (De Villiers 2013:137-152). Miracles are to be scrutinised in order to discern the demonic manifestations and establish theological authenticity. Miracles cannot verify themselves; they need an external extraordinary authority to validate them. In this case, they are measured by the canonical stipulations. The question that lingers all the time is whether these miracles are used to prove God (his existence or his ability), or to prove faith of those who seek after them. If it is to prove God, then the caution is that 'the verification of God outside of faith is impossible for man's sake' (König 1982:138). If it is to prove the faith of the practitioners, then the apostolic caution is 'we live by faith, not by sight' (2 Cor 5:7). There is no need to see in order to believe; lest faith becomes a temporary element of reality.

The community of faith has the legitimate right (exousia) to check and discern miracles, as fake and deceit are rife in today's Neo-charismatic circles. The authority by which miracles are performed must be exposed. Because lots of exorcism is applied, the origin of the miraculous must be identified (judged) in order to validate the genuineness of the miraculous event. It is highly possible for the miracle worker to elevate herself to the higher pedestal, and throw the community into confusion and chaos:

Ecclesiological problems emerge when the ministry of the Church becomes subject to the preferences and proclivities of individuals which sometimes leads to confusion and controversy. (Bate 2012:85)

Lastly, miracles, although not an article of faith, arouse interest or point people towards God, not towards the performer or an agent. Conclusion is made that there are no compelling scientific, philosophical, or theological reasons to write off the possibility of miracles, whether healings or exorcisms or similar' (Kärkkäinen 2016:372). It is theologically legitimate to accept that 'a miracle turns people's eyes upwards, towards God ... miracles concern belief in God and his glorification' (Kasper 1985:92). Miracles are examined by the criteria that are generally used to establish the historical Jesus. They confirm the kerygma - verbal revelation. Miracles do not establish the credentials or the character of the agent. Jesus resisted the temptation when he was cornered with the question: 'By what authority are you doing these things ... And who gave you authority to do this?' He did not want his deeds and actions to be ego-directed, but theocentric. He did not want to attach his credentials to any human figure or institution. Fernando (1995:65-66) emphasises the fact that in the New Testament, it was Jesus who performed miracles, and the three reasons for these miracles were to show compassion, to glorify God and to give evidence to support his claims.

In the current scenario, miracles are the magnet towards the preacher instead of a propeller towards God. Hence, pilgrimages to a particular geographical location or a human 
figure have become a norm. Miraculous powers are associated with a particular personality or a cultic centre (celebrity and centre cult). This tendency questions faith in the omnipotence and the omnipresence of God.

The bottom line is miracles involve the extraordinary, the unusual and the amazing. A miracle is a result of a personal initiative of God. Hence, "the term "miracle" is linked with the "supernatural"' (Kärkkäinen 2015:187). Miracles are a direct divine action, "unless they are "violations" of natural laws - happen within the fabric of natural causes and thus represent indirect actions of God' (Kärkkäinen 2015:192).

They will always be open to interpretations, hence need to be theologically critiqued. They must be opened to spiritual discernment and scrutiny. This is confirmed by Kasper (1985) that:

This polyvalence is also the scope of faith's freedom of choice. A miracle can only be seen as the act of God by faith. It does not force faith, but challenges it and makes it credible. (p. 95)

\section{Conclusion}

Kärkkäinen (2016:375) makes an appeal that we should 'attempt a constructive theology of restoration, healing, and charismatic endowment for the sake of our pluralistic world'. In Africa, miracles are seen as the validation of the Person and the Power of Jesus Christ. Theology must rightly interest itself in the meaning of the mighty deeds of Jesus and his person. In another place, Kärkkäinen (2013) reinforces this fact that:

In Africa, health means not only lack of sickness but also wellbeing in a holistic sense. Sickness is not primarily a result of physical symptoms but also of deeply spiritual causes. (p. 63)

Miracles are the divine intervention where laws of nature are suspended for the purpose of God to prevail. There is a proliferation of miracles in the Neo-charismatic churches in South Africa and elsewhere. Most if not all of the events knighted miracles are human orchestrated; therefore, critically subjected to ecclesiastical and doctrinal scrutiny, analysis and evaluation. However, the thesis remains: miracles, in their original and pure form, are above nature; and count as acts of God. They 'are the visible heraldings of the salvation which frees men and redeems the world' (Moltmann 1989:40). The Christian theologians spent a great deal of time in trying to validate the theological authenticity of miracles. Many of their conclusions came to the crossroads. The remaining factor is that miracles are still possible. However, it has been:

evidently assumed that not only can God and his plenipotentiaries perform miracles and signs, but so can the devil and his demonic angels, and even false prophets and the Antichrist. (Keller \& Keller 1969:16)

This necessitates the examination of the essence, validity and the authenticity of both a miracle and a miracle worker himself. Modesty must prevail as Christ; the great miracle worker himself respects the dignity of humanity. There will be no theological scrutiny if all preachers and theologians understand that 'The ordinary is not graceless, nor is it abandoned in the midst of extraordinary signs and wonders' (Macchia 2006:147). The core of the matter is miracles must be Christocentric, not egocentric. Miracles take the audience by surprise. Because miracles are mentioned in the list of charismata as a corollary gift in the Pauline literature, they are to operate symbiotically with other gifts especially the gift of discernment. Land (2010) attests to the fact that:

Discernment of spirits then seeks to determine the source and evaluate the results of spiritual manifestations and teachings by means of the gift of the Spirit and the Word in the body of believers. (p. 162)

At the Lausanne Congress held in Cape Town, 2010, the African delegates spent $3 \mathrm{~h}$ debating and exploring the dangers of the gospel of health and wealth. Some testimonies were painful as people were robbed of their possessions under the guise of 'the Lord says give away your property or your bank account balance!' Consequent to the Congress, an article by Mikael Stenhammer (09 May 2010) was circulated. The following is quoted from for hermeneutical solution:
A big problem we have to face is that the gospel of wealth is folk theology (or folk hermeneutics). The direct consequence of this is that academic writings and arguments are often ineffective. What is needed is to popularize quality material in a form that connects with the especially the leaders who have not studied theology at all (and for whom theology often is looked upon as something of a hindrance rather than help). We have to find ways of spreading knowledge of what is proper and improper usage of Scripture. The greatest number of those following and preaching prosperity are good and godly people who are convinced that what they believe is truly what the Bible teaches. 'The Bible says it; I believe it; that settles it' is a famous dictum in the Word of Faith movement. So if they find out that the central points of the Prosperity Gospel are not in line with a proper usage of Scripture, then many are ready to change. ${ }^{8}$

The church in South Africa desperately needs the teaching on discipleship based on proper hermeneutics. The correct theological training and Biblical exposition should take the centre stage of ecclesiastical endeavours. Because the notion of power is crucial in African spirituality (Nkurunziza 2013:34), endeavours should be undertaken to bring hermeneutical understanding of power, in order to stave off the possible abuses under the guise of miracles. The theology of the cross is a missing ethology among these charismatics, and attempts must be undertaken to inculcate this theology in any pastoral training and ministerial formation. It is to be acknowledged and accepted that the cross is not only to be interpreted as a source of victory, but also as a symbol of shame, humiliation and suffering (Ngong 2014:6; cf. Asamoah-Gyadu 2013:105-120). 
Like in all Christian practices, modern-day miracles should be cognisant of the reality of context. The poor must never be exploited. 'An authentic response to a context like this requires a response to the complexus of truth, beliefs and values within the context' (Bate 2012:72).

\section{Acknowledgements Competing interests}

The author declares that he has no financial or personal relationships that may have inappropriately influenced him in writing this article.

\section{References}

Asamoah-Gyadu, J.K., 2013, Contemporary Pentecostal Christianity: Interpretation from an African context, Wipf \& Stock, Eugene, $\mathrm{OR}$.

Bate, S.C., 2012, 'A theological model of healing to inform an authentic healing ministry', Journal of Theology for Southern Africa 144, 69-91.

Berkhof, L., 1941, Systematic theology, The Banner of Truth Trust, London.

Brown, C., 1984, Miracles and the critical mind, W.M. Eerdmans Publishing Co., Grand Rapids, MI.

Brunner, E., 1934, The mediator: A study of the central doctrine of the Christian faith, Lutterworth Press, London.

Chadwick, H., (ed.), 1956, Lessing's theological writings, Adam \& Charles Black, London.

De Klerk, J.C. \& Schnell, C.W., 1987, A new look at Jesus: Literary and sociologicalhistorical interpretation of Mark and John, J.L. van Schaik, Pretoria.

De Villiers, P.G.R., 2013, 'Communal discernment in the early church', Acta Theologica Supplementum 7, 132-155.

Elwes, R.H.M., 1955, The chief works of Benedict de Spinoza, vol. 1, Dover Publications, New York.

Fernando, A., 1995, The supremacy of Christ, Crossway Books, Wheaton, IL.

Kärkkäinen, V.-M., 2013, Christ and reconciliation, vol. 1, WB Eerdmans, Grand Rapids, MI.

Kärkkäinen, V.-M., 2015, Creation and humanity, vol. 3, WB Eerdmans, Grand Rapids, MI.
Kärkkäinen, V.-M., 2016, Spirit and salvation, vol. 4, WB Eerdmans, Grand Rapids, MI. Kasper, W., 1985, Jesus the Christ, Burns and Oates Limited, London.

Keller, E. \& Keller, M.-L., 1969, Miracles in dispute: A continuing debate, SCM Press, London.

König, A., 1982, Here Am I: A believer's reflection on God, Marshall Morgan \& Scott, London.

Land, S.J., 2010, Pentecostal spirituality: A passion for the Kingdom, CPT Press, Cleveland, $\mathrm{OH}$.

Macchia, F.D., 2006, Baptized in the spirit: A global Pentecostal theology, Zondervan Publishing House, Grand Rapids, MI.

Macquarrie, J., 1971, Principles of Christian theology, SCM Press, London.

Macquarrie, J., 1997, Jesus Christ in the modern thought, SCM Press, London.

Merrill, E.H., 1994, Historical survey of the Old Testament, (2nd ed)., Baker Book House, Grand Rapids, MI.

Mokubung, T., Ngcobo, N. \& Ngwenya, K., 2014, 'Nigerian collapse: SA's preachers speak out', DRUM Magazine, 09 October, pp. 18-20.

Moltmann, J., 1989, The church in the power of the spirit, SCM Press, London.

Moule, C.F.D., 1966, Miracles: Cambridge studies in their philosophy and history, A.R. Mowbray \& Co, London.

Ngong, D.T., 2014, 'Protesting the cross: African Pentecostal Soteriology and Pastoral Care', Journal of Theology for Southern Africa 150, 5-19.

Nkurunziza, C., 2013, 'Pentecostal spirituality: A disregarded cornerstone for the contextualisation of African theologies', Journal of Theology for Southern Africa 145, 59-74.

Price, G. \& Price, H., 1995, Miracles: True stories of how god acts today, Macmillan, London.

Shenk, W.R., 2005, 'New wineskins for new wine: Toward a post-Christendom ecclesiology', International Bulletin of Mission Research 29(2), 73-79. https://doi. org/10.1177/239693930502900203

Siggins, I.D.K., 1970, Martin Luther's Doctrine of Christ, Yale Publications in Religion, Yale University Press, New Haven, CT.

Times Live Daily News. 11 July 2015, viewed 13 August 2016, from http://www. timeslive.co.za/entertainment/article1450824.ece

Van Der Meer, F., 1966, The faith of the Church, Darlton, Longman \& Todd, London.

Wanner, Z., 2012, 'A swig of paraffin with your peanuts', Sunday Times Newspaper, 26 October, p. 8.

Warrington, K., 2008, Pentecostal theology: A theology of encounter, T \& T Clark, London.

Yong, A. \& Anderson, A., 2014, Renewing Christian theology: Systematics for a global Christianity, Baylor University Press, Waco, TX. 